\title{
Dietary $n-3$ fatty acids affect mRNA level of brown adipose tissue uncoupling protein 1 , and white adipose tissue leptin and glucose transporter 4 in the rat
}

\author{
Yoko Takahashi and Takashi Ide* \\ Laboratory of Nutrition Biochemistry, National Food Research Institute, Ministry of Agriculture, \\ Forestry and Fisheries, 2-1-2 Kannondai, Tsukuba Science City, Ibaraki 305-8642, Japan \\ (Received 11 May 1999 - Revised 7 December 1999 - Accepted 20 December 1999)
}

\begin{abstract}
We examined the effect of dietary fats rich in $n-3$ polyunsaturated fatty acids (PUFA) on mRNA levels in white and brown adipose tissues in rats. Four groups of rats were fed on a low-fat diet (20 g safflower oil $/ \mathrm{kg}$ ) or a high-fat diet $(200 \mathrm{~g} / \mathrm{kg})$ containing safflower oil, which is rich in $n-6$ PUFA (linoleic acid), or perilla ( $\alpha$-linolenic acid) or fish oil (eicosapentaenoic and docosahexaenoic acids), both of which are rich in $n$-3 PUFA, for $21 \mathrm{~d}$. Energy intake was higher in rats fed on a high-safflower-oil diet than in those fed on low-fat or high-fish-oil diet, but no other significant differences were detected among the groups. Perirenal white adipose tissue weight was higher and epididymal white adipose tissue weight tended to be higher in rats fed on a highsafflower-oil diet than in those fed on a low-fat diet. However, high-fat diets rich in $n-3$ PUFA, compared to a low-fat diet, did not increase the white adipose tissue mass. High-fat diets relative to a low-fat diet increased brown adipose tissue uncoupling protein $1 \mathrm{mRNA}$ level. The increases were greater with fats rich in $n$-3 PUFA than with $n$-6 PUFA. A high-safflower-oil diet, compared to a low-fat diet, doubled the leptin mRNA level in white adipose tissue. However, high-fat diets rich in $n$-3 PUFA failed to increase it. Compared to a low-fat diet, high-fat diets down-regulated the glucose transporter 4 mRNA level in white adipose tissue. However, the decreases were attenuated with high-fat diets rich in $n-3$ PUFA. It is suggested that the alterations in gene expression in adipose tissue contribute to the physiological activities of $n-3$ PUFA in preventing body fat accumulation and in regulating glucose metabolism in rats.
\end{abstract}

\section{n-3 Fatty acids: Adipose tissue: Gene expression: Leptin}

Adipose tissue, the energy reserve organ, plays a global role in regulating energy metabolism in organisms (Hwang et al. 1997). Mature white adipocytes express proteins related to the regulation of lipid and carbohydrate metabolism, and secretory cytokines and hormones that affect energy metabolism in other tissues. Another tissue that plays a critical role in regulating energy metabolism is brown adipose tissue, which controls energy balance by thermogenesis through the unique action of uncoupling protein (UCP) 1, which is highly expressed in this tissue (Himms-Hagen, 1990). Conceivably, alterations in the expression of proteins regulating lipid and carbohydrate metabolism and energy expenditure in these tissues affect the development of obesity and related diseases.

One dietary factor affecting body fat mass and the functions of white and brown adipose tissue is the dietary fat type. Recent studies indicated that, compared to saturated fats and fats rich in polyunsaturated fatty acids (PUFA) of $n$-6 series (linoleic acid), fish oil rich in very-long-chain n-3 PUFA (eicosapentaenoic and docosahexaenoic acids) (Belzung et al. 1993; Oudart et al. 1997; Raclot et al. 1997; Kawada et al. 1998) and perilla oil rich in $\alpha$-linolenic acid (Okuno et al. 1997) reduce white fat pad mass. Regarding the mechanism by which $n-3$ PUFA cause less body fat accumulation, some studies (Oudart et al. 1997; Kawada et al. 1998) have indicated that they increase thermogenesis in brown adipose tissue. It has also been demonstrated that, compared to dietary fats rich in linoleic acid, fish oil increases insulin-stimulated glucose transport and metabolism in isolated white adipocytes (Ezaki et al. 1992; Luo et al. 1996; Huang et al. 1997). It is apparent therefore that $n-3$ PUFA affect adipose tissue metabolism. It is plausible that $n$-3 PUFA modify gene expression of proteins that regulate adipose metabolism and thereby exert their physiological activity. However, information regarding the effect of dietary fats rich in $n-3$ PUFA on gene expression of white and brown adipose tissues is still rather scarce (Okuno et al. 
1997; Raclot et al. 1997). In this context, we compared the effects of a low-fat diet and high-fat diets containing safflower oil rich in linoleic acid, perilla oil rich in $\alpha$-linolenic acid, and fish oil rich in very-long-chain $n$-3 PUFA on the abundance of mRNA for proteins regulating energy expenditure and lipid and carbohydrate metabolism in white and brown adipose tissues. We analysed mRNA levels of UCP 1, leptin, glucose transporter (Glut) 4, and lipoprotein lipase (LPL). Mitochondrial protein called UCP 1, which is solely expressed in brown adipose tissue, induces non-shivering thermogenesis by creating a pathway that allows dissipation of the proton electrochemical membrane (Nicholls \& Locke, 1984). Leptin is the product of the $o b$ gene (Zhang et al. 1994) and is one of the regulators of food intake and body fat mass. Glut 4 is the insulin-responsive glucose transporter and plays an important role in whole-body glucose homeostasis (Ezaki et al. 1992; Kahn, 1994). LPL is responsible for catabolism of the triacylglycerol core of circulating chylomicrons and VLDL into non-esterified fatty acids and glycerol (Ramsay, 1996). Adipocytes take up liberated fatty acids and esterify them into triacylglycerol for storage purposes. As these proteins play a crucial role in regulating adipose tissue metabolism, examination of mRNA level for these proteins in rats fed fats rich in $n$ - 3 PUFA may clarify the mechanism by which $n-3$ PUFA exert physiological activity in regulating white pad mass and glucose metabolism.

\section{Materials and methods}

\section{Animals and diets}

Male Sprague-Dawley rats, purchased at 5 weeks of age (Charles River Japan, Kanagawa, Japan), were housed individually in a room with controlled temperature (20$22^{\circ}$ ), humidity $(55-60 \%$ ), and lighting (lights on from 07.00 hours to 19.00 hours) and fed on a commercial nonpurified diet (Type NMF, Oriental Yeast, Tokyo, Japan). After $7 \mathrm{~d}$ of acclimation to the housing conditions, rats were randomly divided into four groups consisting of seven animals each and fed on a purified diet containing $20 \mathrm{~g}$ safflower oil $/ \mathrm{kg}$ or diets containing $200 \mathrm{~g}$ safflower, perilla or fish oil $/ \mathrm{kg}$ for $21 \mathrm{~d}$. The basal composition of the experimental diet is shown in Table 1. Dietary fats were added to experimental diets in lieu of sucrose. The fatty acid compositions of dietary fats are shown in Table 2 . Body weight at the start of the experiment was 199-216 g. We followed the guidelines of our Institute in the care and use of laboratory animals.

\section{Preparation of cDNA probes}

Reverse transcription followed by polymerase chain reaction was performed to prepare cDNA probes for UCP 1, leptin, Glut 4, and LPL using a kit (Gene Amp ${ }^{\circledR}$ RNA PCR kit, Perkin Elmer, Foster City, CA, USA) as recommended by the manufacturer. First-strand cDNA synthesized from white adipose tissue RNA was used for the polymerasechain-reaction amplification of probes for leptin, Glut 4, and LPL. A probe for UCP 1 was prepared by PCR amplification using first-strand cDNA synthesized from brown adipose tissue RNA. Primers used for polymerase-chain-reaction
Table 1. Basal composition ( $\mathrm{g} / \mathrm{kg}$ diet) of experimental diets

\begin{tabular}{lcc}
\hline Ingredients & Low-fat diet & High-fat diet \\
\hline Fat $^{\star}$ & 20 & 200 \\
Casein & 200 & 200 \\
Corn starch & 150 & 150 \\
Sucrose & 560 & 380 \\
Cellulose & 20 & 20 \\
Mineral mixture & 35 & 35 \\
Vitamin mixture & 10 & 10 \\
DL-Methionine & 3 & 3 \\
Choline bitartrate & 2 & 2 \\
\hline
\end{tabular}

* Safflower oil was used for a low-fat diet. Either safflower, perilla or fish oil was used for a high-fat diet. Dietary fats were added to experimental diets in lieu of sucrose.

†The composition was that recommended by the American Institute of Nutrition (1977).

amplification of cDNA probes were designed based on reported cDNA sequences (Bouillaud et al. 1986; James et al. 1989; Brault et al. 1992; Ogawa et al. 1995). DNA sequences of upstream and downstream primers were: $5^{\prime}$ CAGACATCATCACCTTCCCG-3' and 5'-AAGTCGCCTATGTGGTGCAG-3' for UCP 1; 5'-TCCAAGAAGAAGAAGACCCCA-3' and 5'-GAGGAGTAGGAGAAACGGAC3' for leptin; 5'-GACACTGGTCCTTGCTGTAT-3' and 5'-CATCAGACACATCAGCCCAG-3' for Glut 4; 5'-TGTCTAACTGCCACTTCAACC-3' and 5'-TTACTGCTTCTCTTGGCTCTG-3' for LPL. DNA sequences of the amplification products were partially determined by direct sequencing to confirm their identities with reported cDNA sequences of corresponding proteins. Polymerase-chainreaction products were purified by agarose gel electrophoresis and used as probes to detect mRNA for the respective proteins. cDNA probe for $\beta$-actin was obtained from Wako Pure Chemicals, Osaka, Japan.

\section{RNA extraction and analysis}

At the end of the experimental period, rats were anaesthetized with diethyl ether and killed by bleeding from the abdominal aorta. Epididymal and perirenal white adipose tissues and interscapular brown adipose tissue were quickly excised. Brown adipose tissue was carefully cleaned from

Table 2. Fatty acid composition ( $\mathrm{g} / 100 \mathrm{~g}$ total fatty acids) of dietary fats

\begin{tabular}{lccr}
\hline & \multicolumn{3}{c}{ Dietary fats } \\
\cline { 2 - 4 } Fatty acids & Safflower oil & Perilla oil & Fish oil \\
\hline $14: 0$ & $0 \cdot 1$ & - & $2 \cdot 2$ \\
$16: 0$ & $6 \cdot 9$ & $5 \cdot 8$ & $13 \cdot 1$ \\
$16: 1 n-7$ & - & $0 \cdot 3$ & $6 \cdot 9$ \\
$18: 0$ & $2 \cdot 4$ & $1 \cdot 6$ & $3 \cdot 0$ \\
$18: 1 n-9$ & $13 \cdot 0$ & $14 \cdot 8$ & $21 \cdot 5$ \\
$18: 2 n-6$ & $77 \cdot 3$ & $13 \cdot 9$ & $2 \cdot 1$ \\
$18: 3 n-3$ & $0 \cdot 2$ & $63 \cdot 0$ & $0 \cdot 7$ \\
$20: 4 n-6$ & - & - & $3 \cdot 0$ \\
$20: 5 n-3$ & - & - & $10 \cdot 0$ \\
$22: 4 n-6$ & - & - & $0 \cdot 7$ \\
$22: 5 n-6$ & - & - & $1 \cdot 7$ \\
$22: 5 n-3$ & - & - & $2 \cdot 6$ \\
$22: 6 n-3$ & - & - & $32 \cdot 6$ \\
\hline
\end{tabular}


the surrounding muscular tissue and white adipose tissue. White and brown adipose tissues were homogenized in $4 \mathrm{M}$-guanidine thiocyanate solution containing $5 \mathrm{~g}$ sodium $N$-lauroyl sarcosianate/l, $25 \mathrm{mM}$-sodium citrate $(\mathrm{pH} \mathrm{7 \cdot 0)}$, and $0 \cdot 1 \mathrm{M}$-2-mercaptoethanol (five volumes of the solution relative to tissue weight was used for white adipose tissue, and ten volumes was used for the brown adipose tissue). Homogenates were centrifuged at $2000 \mathrm{~g}$ for $10 \mathrm{~min}$. Infranatants below the floating fat layer were processed to extract RNA according to the method of Chomczynski \& Sacchi (1987). RNA samples were denatured and applied to a nylon membrane using a slot-blot apparatus (Bio-Rad Laboratories, Hercules, CA, USA) and fixed with u. v. irradiation. Northern-blot analysis was conducted by standard procedures. RNA samples were denatured and electrophoresed on an agarose gel $(11 \mathrm{~g} / \mathrm{l})$ containing $0.66 \mathrm{M}$-formaldehyde, subsequently transferred to a nylon membrane and fixed with u.v. irradiation. Equal loading and integrity of RNA samples were confirmed by ethidium bromide fluorescence of ribosomal $18 \mathrm{~S}$ and 28S RNA. mRNA on nylon membrane were detected using cDNA probes labelled with $\left[\alpha-{ }^{32} \mathrm{P}\right] \mathrm{dCTP}$. A kit purchased from Takara Co., Kyoto, Japan (Random Primer DNA Labeling Kit Ver. 2.0) was used for DNA radiolabelling. RNA hybridized with specific cDNA probes was analysed and quantified using an imaging analyser (Bio-Rad Laboratories).

\section{Lipid analysis}

Serum lipids were extracted and purified (Folch et al. 1957). Triacylglycerol and phospholipid concentrations in extracts were determined as described elsewhere (Ide et al. 1978). Serum cholesterol and glucose concentrations were assayed using commercial enzyme kits (Wako Pure Chemical, Osaka, Japan). Fatty acid compositions of dietary fats and white adipose tissues were determined by GLC as described elsewhere (Ide et al. 1978).

\section{Statistics}

Levene's test was used to inspect the constancy of the variance of the observations. If variances were heterogeneous, the observations were transformed logarithmically and these values were used for subsequent statistical evaluations. Logarithmic transformations were successful in making the variance of the observations constant. The data were analysed by one-way ANOVA and subsequently examined for significant differences of the means with a pooled estimate of variance (Snedecor \& Cochran, 1989; Ide et al. 1994). Significance of correlation between white pad mass and mRNA level was estimated as described by Snedecor \& Cochran (1989) using calculated value of correlation coefficient.

\section{Results}

There was no difference in growth among the groups (Table 3). The amount of diet consumed was significantly higher in the low-fat than the high-fat groups. Among the high-fat groups, it was significantly higher in rats fed on safflower oil than in those fed on fish oil. However, no other significant difference was noted among the groups of rats fed on high-fat diets. Spillage of diets, if any, was minimal in our experimental conditions. Gross energy intake was significantly higher in rats fed on a high-safflower-oil diet than in those fed on a low-fat or high-fish-oil diet.

Perirenal white adipose tissue weight was significantly higher in rats fed on a diet containing $200 \mathrm{~g}$ safflower oil $/ \mathrm{kg}$ than in those fed on a low-fat diet. Epididymal white adipose tissue weight tended to be higher in the highsafflower-oil diet group than in the low-fat group. However, white adipose tissue weight in rats receiving diets containing $200 \mathrm{~g}$ fats rich in $n-3$ PUFA/kg, i.e. either perilla or fish oil, was comparable to or even lower in one occasion (epididymal depot in rats fed on fish oil) than the value in rats fed on a low-fat diet. As a result, both epididymal and perirenal tissue weights were significantly lower in the perilla and fish-oil groups than in the safflower-oil group among the rats fed on high-fat diets. Brown adipose tissue weight did not vary among the groups.

In a preliminary study, we analysed RNA extracted from epididymal white adipose tissue, brown adipose tissue, liver, and heart in rats fed on a laboratory chow by Northern blotting using cDNA probes prepared by reverse transcription

Table 3. Effects of dietary fats on growth variables and adipose tissue weight in rats* (Mean values and standard deviations for seven rats per group)

\begin{tabular}{|c|c|c|c|c|c|c|c|c|c|}
\hline & & & \multicolumn{6}{|c|}{ High-fat diets } & \multirow[b]{3}{*}{ Pooled SD } \\
\hline & \multicolumn{2}{|c|}{ Low-fat diet } & \multicolumn{2}{|c|}{ Safflower oil } & \multicolumn{2}{|c|}{ Perilla oil } & \multicolumn{2}{|c|}{ Fish oil } & \\
\hline & Mean & SD & Mean & SD & Mean & SD & Mean & SD & \\
\hline $\begin{array}{l}\text { Body-weight gain }(g / 21 d) \\
\text { Food intake }(g / d) \dagger\end{array}$ & $\begin{array}{l}177 \\
26 \cdot 0^{c}\end{array}$ & $\begin{array}{l}11 \\
0.7\end{array}$ & $\begin{array}{l}212 \\
23 \cdot 5^{b}\end{array}$ & $\begin{array}{l}41 \\
2 \cdot 7\end{array}$ & $\begin{array}{l}194 \\
21 \cdot 8^{\mathrm{ab}}\end{array}$ & $\begin{array}{c}27 \\
1.6\end{array}$ & $\begin{array}{l}187 \\
20 \cdot 2^{\mathrm{a}}\end{array}$ & $\begin{array}{c}16 \\
1.3\end{array}$ & $\begin{array}{l}26 \\
2 \cdot 0\end{array}$ \\
\hline $\begin{array}{l}\text { Gross energy intake }(\mathrm{kJ} / \mathrm{d}) \dagger \\
\text { Epididymal white adipose tissue } \\
\text { (q/100 q body weight) }\end{array}$ & $\begin{array}{l}467^{\mathrm{a}} \\
2 \cdot 25^{\mathrm{bc}}\end{array}$ & $\begin{array}{l}13 \\
0.44\end{array}$ & $\begin{array}{l}515^{\mathrm{b}} \\
2 \cdot 63^{\mathrm{c}}\end{array}$ & 59 & $\begin{array}{l}478^{a b} \\
1.96^{a b}\end{array}$ & $\begin{array}{l}35 \\
0.14\end{array}$ & $\begin{array}{l}444^{\mathrm{a}} \\
1.66^{\mathrm{a}}\end{array}$ & $\begin{array}{l}29 \\
0.34\end{array}$ & 38 \\
\hline $\begin{array}{l}\text { Perirenal white adipose tissue } \\
\text { ( } \mathrm{g} / 100 \mathrm{~g} \text { body weight) }\end{array}$ & $2 \cdot 29^{a}$ & 0.23 & $3.03^{b}$ & 0.44 & $2 \cdot 41^{a}$ & 0.41 & $1.97^{\mathrm{a}}$ & 0.56 & 0.42 \\
\hline $\begin{array}{l}\text { Interscapular brown adipose tissue } \\
\text { ( } \mathrm{g} / 100 \mathrm{~g} \text { body weight) }\end{array}$ & 0.186 & 0.038 & $0 \cdot 195$ & 0.029 & 0.205 & 0.027 & 0.181 & 0.020 & 0.029 \\
\hline
\end{tabular}

\footnotetext{
${ }^{a, b, c}$ Mean values within a row with unlike superscript letters were significantly different, $P<0.05$.

${ }^{*}$ For details of diets see Tables 1 and 2 .

†Values were logarithmically transformed before analysis by ANOVA, and transformed values were inspected for significant differences of means.
} 
and polymerase-chain-reaction amplification. UCP 1 mRNA was detected only in brown adipose tissue among the tissues examined. Leptin gene expression was the highest in white adipose tissue, and a weak but significant mRNA signal was detected in brown adipose tissue, but not in the heart or liver. The mRNA signal for Glut 4 was detected in white and brown adipose tissue and the heart but not in the liver. The intensity of the mRNA signal for LPL was the highest in white adipose tissue, and less intense but significant in the heart and brown adipose tissue, while negligible in the liver. These results agree with the previous observations (Jacobsson et al. 1985; James et al. 1989; Semenkovich et al. 1989; Zhang et al. 1994) regarding the tissue distribution of mRNA for the respective proteins and thus confirm the specificity of our cDNA probes. Size of mRNA has been reported to be $4.5 \mathrm{~kb}$ for leptin (Ogawa et al. 1995), $2.8 \mathrm{~kb}$ for Glut 4 (James et al. 1989), and $3.6 \mathrm{~kb}$ for LPL (Kirchgessner et al. 1987) respectively. The values as estimated using $18 \mathrm{~S}$ and $28 \mathrm{~S}$ ribosomal RNA as relative molecular mass markers in the present study, conformed with those previously reported. There are two mRNA for UCP 1 differing in relative molecular mass in rodents $(1.6$ and $1.9 \mathrm{~kb}$ for rats and 1.3 and $1.7 \mathrm{~kb}$ for mouse). However, in the present study, our probe detected only a smaller isoform of UCP 1 mRNA. In this context, it has been reported that smaller isoform predominates under various nutritional and physiological conditions (Ricquier et al. 1984, 1986; Bouillaud et al. 1985; Martin et al. 1995).

As preliminary experiments confirmed the specificity of our cDNA probes, mRNA abundance was analysed by slotblot hybridization using duplicated membranes for each probe. Values for each tissue were expressed relative to a value of 100 for rats fed on a low-fat diet. Because of the large number of samples to be analysed in this study, it was not possible to load all the RNA samples from all tissues in a same membrane. Accurate estimation of the differences in the mRNA abundances among tissues was therefore difficult in this study. We analysed the RNA from epididymal and perirenal white adipose tissues, and brown adipose tissue in rats fed on a low-fat diet in the same membrane to estimate the differences in the mRNA level among these tissues. UCP 1 mRNA was detected in brown adipose tissue, but not in white adipose tissue. Leptin mRNA abundance was approximately the same in perirenal and epididymal white adipose tissues, and Glut $4 \mathrm{mRNA}$ level was $50 \%$ higher in perirenal than in epididymal white adipose tissue. mRNA signals for these proteins were detected in brown adipose tissue, however, they were too low to obtain reliable values. LPL mRNA abundance was approximately the same in epididymal and perirenal white adipose tissues, and 75-80\% lower in brown adipose tissue. The mRNA level of a housekeeping gene ( $\beta$-actin) was comparable in epididymal and perirenal white adipose tissues, while that in brown adipose tissue was too low to obtain a reliable value.

Although we did not measure the total RNA level in adipose tissue in this study, extracted amounts of RNA from white and brown adipose tissues using the method of Chomczynski \& Sacchi (1987) were comparable among the groups in spite of the fact that dietary fat types significantly affected white pad mass. They were 362 (SD 28), 321 (SD 37), 321 (SD 17) and 275 (SD 18) $\mu \mathrm{g} / 100 \mathrm{~g}$ body weight in epididymal white adipose tissue of rats fed on a low-fat diet and those fed on high-fat diets containing safflower, perilla and fish oils respectively. A significant difference $(P=0.03)$ was noted only between rats fed on a low-fat and high-fish oil diets. No significant differences were observed in the amount of RNA recovered from perirenal white adipose tissue (206-265 $\mu \mathrm{g} / 100 \mathrm{~g}$ body weight) and brown adipose tissue (89-114 $\mu \mathrm{g} / 100 \mathrm{~g}$ body weight) among the groups.

UCP 1 mRNA levels in brown adipose tissue were 150 , 277 and $267 \%$ higher in rats fed on diets containing $200 \mathrm{~g}$ safflower, perilla and fish oils/kg respectively, than in those fed on a low-fat diet (Fig. 1). Among high-fat groups, the value was significantly higher in rats fed on fats rich in $n-3$ PUFA than in those fed on safflower oil. LPL mRNA level in brown adipose tissue was significantly higher in rats fed on various high-fat diets than in those fed on a low-fat diet. However, the differences among the three high-fat diet groups were not significant. Typical results of Northernblotting are also presented in Fig. 1.

Leptin mRNA level in epididymal and perirenal white adipose tissues was 80 and $100 \%$ higher respectively, in rats fed on a high-safflower-oil diet than in those fed on a low-fat diet (Fig. 2). The perirenal white adipose tissue leptin mRNA level was slightly higher $(30 \%)$ in rats fed on a high-perilla-oil diet than in those fed on a low-fat diet. However, no other significant difference in leptin mRNA level was detected between rats fed on a low-fat diet and high-perilla or -fish-oil diet. As a result, the values became significantly lower in rats fed on perilla or fish oil than in the animals fed on safflower oil among the high-fat groups. Epididymal and perirenal white adipose tissue Glut 4 mRNA levels were more than $50 \%$ lower in rats fed on a highsafflower-oil diet than in those fed on a low-fat diet. However, mRNA level for this protein in perirenal white adipose tissue was only 28 and $32 \%$ lower in the rats fed on high-perilla and -fish-oil diets than in those fed on a low fat diet respectively. There was no significant difference in this variable in epididymal white adipose tissue among rats fed on a low-fat diet and the high-fat diets rich in n-3 PUFA. The values both in epididymal and perirenal adipose tissues, therefore, became significantly higher in rats fed on high-fat diets rich in $n-3$ PUFA than in the animals fed on a $200 \mathrm{~g}$ safflower oil $/ \mathrm{kg}$ diet. There were no significant differences in LPL mRNA level among the groups in either epididymal or perirenal white adipose tissue (data not shown). There were no significant differences in epididymal or perirenal white adipose tissue $\beta$-actin mRNA abundance among the groups. Typical results of Northern-blotting were also presented in Fig. 2.

Significant positive correlations $(P<0.01)$ were observed between epididymal and perirenal white adipose tissue weights and leptin mRNA levels in these tissues (Fig. 3). The regression equations were $y=67 \cdot 7 x-13 \cdot 1(r 0 \cdot 627)$ and $y=53 \cdot 2 x+8 \cdot 1(r 0.619)$ for epididymal and perirenal white adipose tissues respectively. There were no significant correlations between white adipose tissue weight and mRNA levels of UCP 1, Glut 4, or LPL (results not shown).

Serum triacylglycerol, cholesterol, and phospholipid concentrations were lower in the high-perilla and -fish-oil groups than in the low-fat group (Table 4). Serum phospholipid 


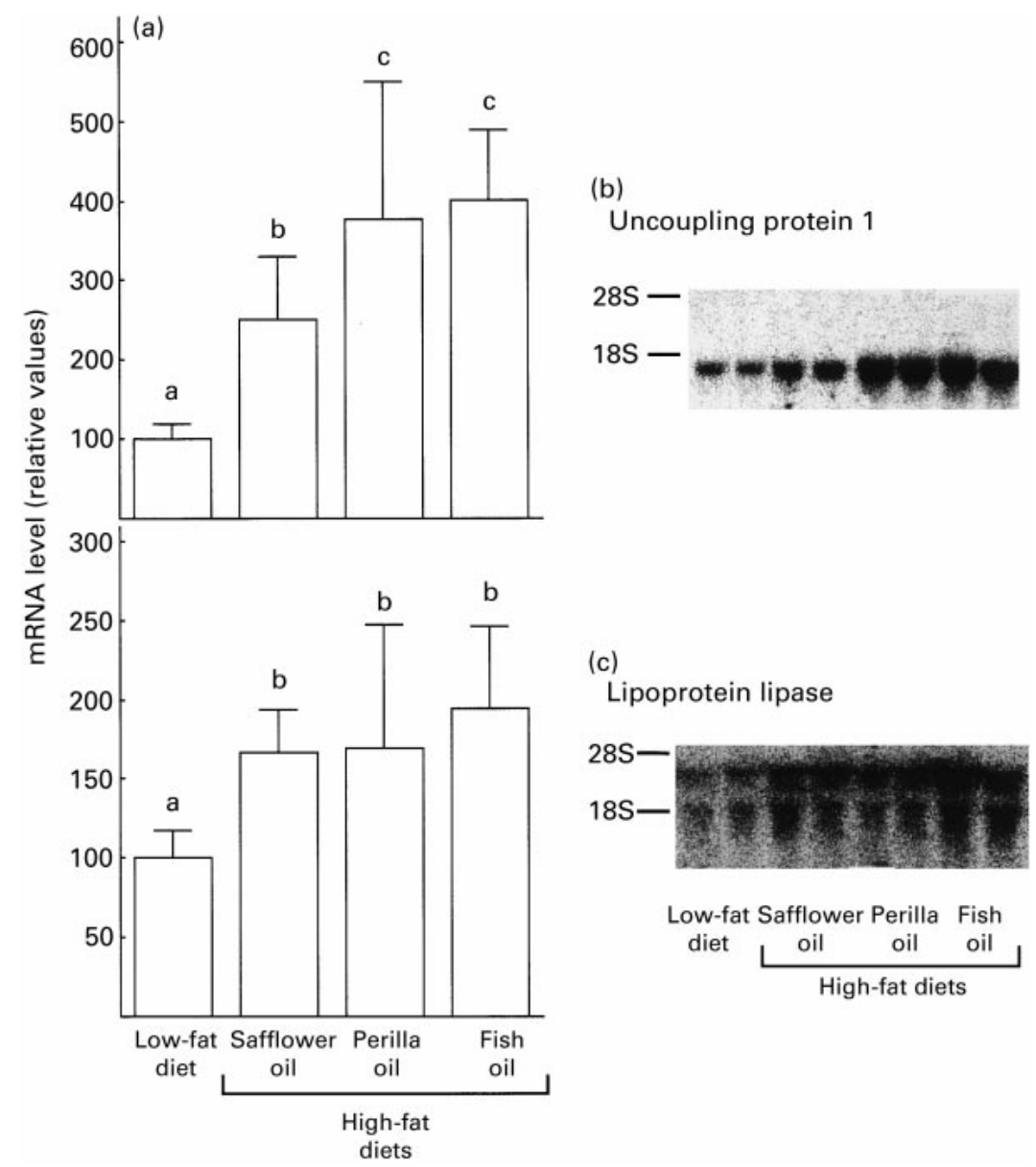

Fig. 1. (a) Effects of dietary fats on the mRNA levels of brown adipose tissue uncoupling protein 1 and lipoprotein lipase. mRNA abundance was analysed by slot-blot hybridization using duplicated membranes for each probe. We used 10 and $20 \mu \mathrm{g}$ of total RNA to quantify uncoupling protein 1 and lipoprotein lipase mRNA levels respectively. Values are expressed relative to a value of 100 for rats fed on a low-fat diet. Values are means for seven rats, with standard deviations represented by vertical lines. Pooled standard deviations were 105 and 49 for uncoupling protein 1 and lipoprotein lipase mRNA respectively. The values for both uncoupling protein 1 and lipoprotein mRNA levels were logarithmically transformed before they were statistically analysed. Mean values with unlike superscript letters were significantly different, $P<0.05$. (b), (c) Typical results for Northern blotting are also presented. Amounts of total RNA analysed were the same as those used for slot-blot hybridization.

concentration was also lower in the high-safflower-oil group than in the low-fat group. No differences in serum triacylglycerol and cholesterol concentrations were, however, seen between these two groups. Among the high-fat groups, serum concentrations of these lipid components were significantly higher in rats fed on safflower oil than in those fed on fats rich in $n-3$ PUFA. Serum glucose concentration became significantly higher in rats fed on a high-safflower-oil diet than in those fed on a low-fat diet. No significant differences in this variable were, however, detected between rats fed on a low-fat diet and those fed on high-fat diets rich in $n-3$ PUFA. As a result, among the high-fat groups, serum glucose concentrations became significantly higher in the safflower-oil group than in the perilla- or fish-oil group.

Table 4. Effects of dietary fats on serum lipid and glucose concentrations ( $\mathrm{mmol} / \mathrm{l})^{\star}$

(Mean values and standard deviations for seven rats per group)

\begin{tabular}{|c|c|c|c|c|c|c|c|c|c|}
\hline \multirow[b]{3}{*}{ Serum components } & & & \multicolumn{6}{|c|}{ High-fat diets } & \multirow[b]{3}{*}{ Pooled SD } \\
\hline & \multicolumn{2}{|c|}{ Low-fat diet } & \multicolumn{2}{|c|}{ Safflower oil } & \multicolumn{2}{|c|}{ Perilla oil } & \multicolumn{2}{|c|}{ Fish oil } & \\
\hline & Mean & $\mathrm{SD}$ & Mean & SD & Mean & SD & Mean & $\mathrm{SD}$ & \\
\hline Triacylglycerol & $1.48^{c}$ & 0.37 & $1 \cdot 29^{b c}$ & 0.34 & $1 \cdot 12^{b}$ & 0.20 & $0.55^{a}$ & 0.16 & 0.28 \\
\hline Cholesterol & $4.00^{b}$ & 0.48 & $3.51^{b}$ & 0.53 & $2 \cdot 32^{a}$ & 0.37 & $1.89^{a}$ & 0.68 & 0.53 \\
\hline Phospholipid & $3.43^{c}$ & 0.34 & $2.95^{b}$ & 0.50 & $2.02^{a}$ & 0.17 & $1.75^{a}$ & 0.52 & 0.40 \\
\hline Glucose & $8 \cdot 00^{a}$ & 2.05 & $9 \cdot 45^{b}$ & 1.52 & $7 \cdot 01^{a}$ & $1 \cdot 37$ & $7 \cdot 51^{a}$ & 1.05 & 1.48 \\
\hline
\end{tabular}

a,b,c Mean values within a row with unlike superscript letters were significantly different, $P<0.05$.

${ }^{*}$ For details of diets see Tables 1 and 2. 

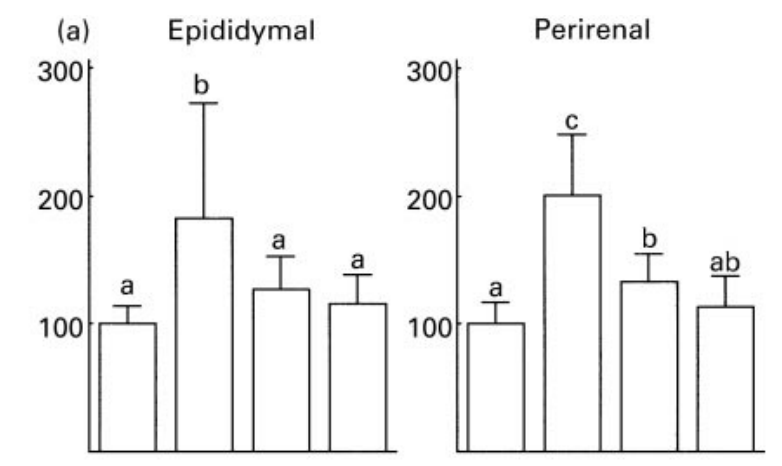

(b)
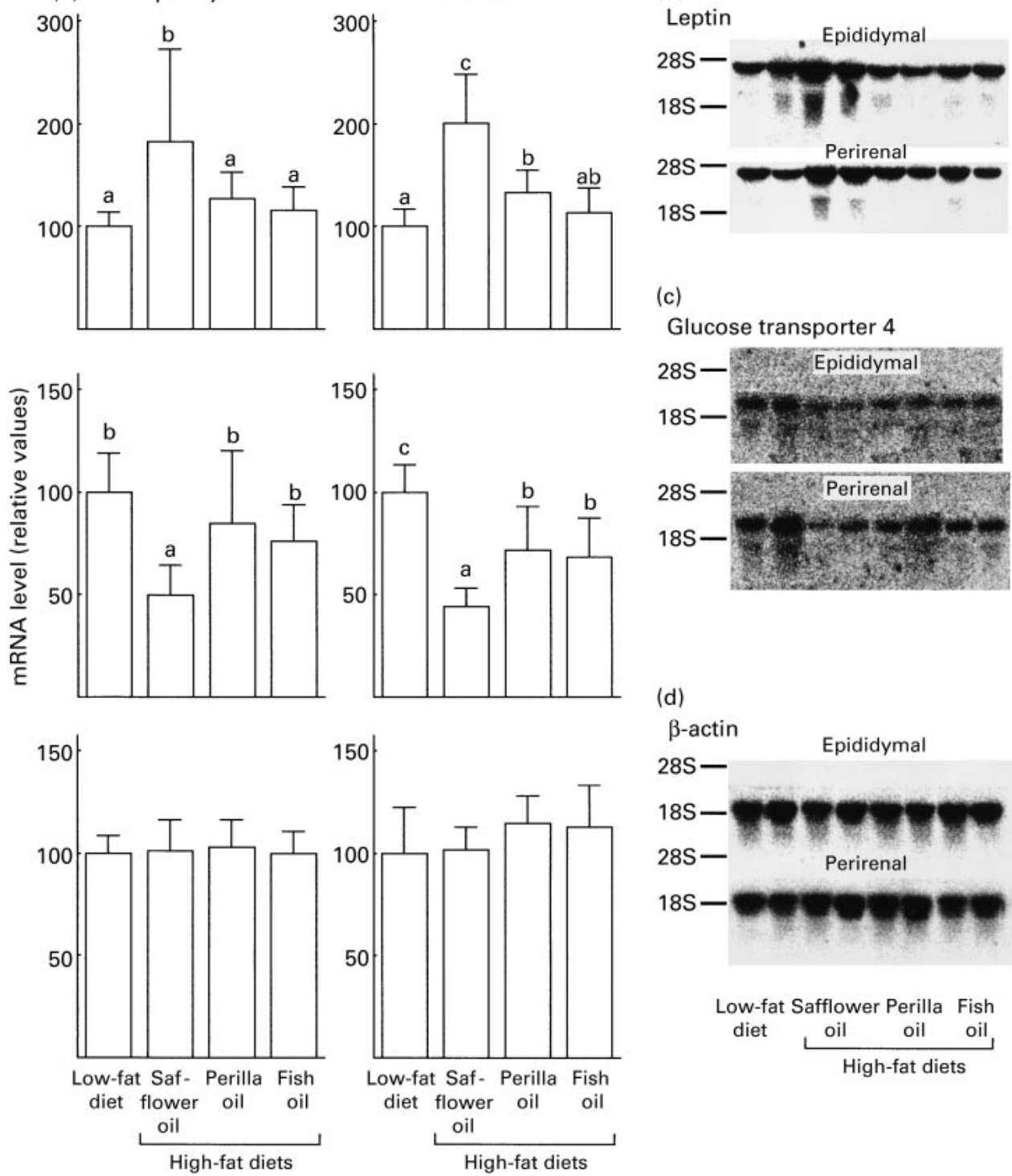

(d)

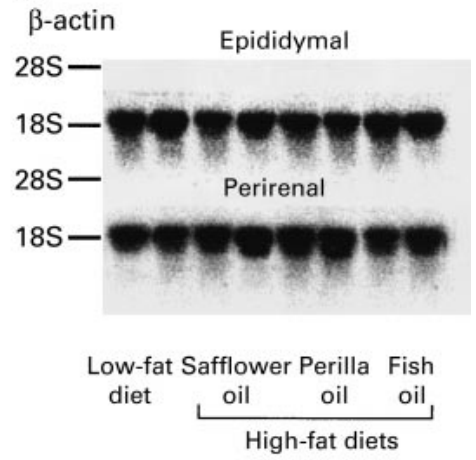

Fig. 2. (a) Effects of dietary fats on the mRNA levels of white adipose tissue leptin, glucose transporter 4 and $\beta$-actin. mRNA abundance was analysed by slot-blot hybridization using duplicated membranes for each probe. We used $40 \mu \mathrm{g}$ of total RNA to quantify glucose transporter 4 mRNA level, and $20 \mu \mathrm{g}$ for both leptin and $\beta$-actin. Values are expressed relative to a value of 100 for rats fed on a low-fat diet. Values are means for seven rats, with standard deviations represented by vertical lines. Mean values with unlike superscript letters were significantly different, $P<$ 0.05. Pooled standard deviations for epididymal and perirenal mRNA levels were 48.6 and 29.9 for leptin, 23.2 and 16.2 for glucose transporter 4 , and 12.1 and 17.5 for $\beta$-actin. The values for epididymal and perirenal leptin mRNA levels were logarithmically transformed before they were statistically analysed. (b), (c), (d) Typical results for Northern blotting are also presented. Amounts of total RNA analysed were the same as those used for slot-blot hybridization.

Fatty acid compositions of epididymal and perirenal adipose tissue resembled each other and were similarly affected by the types of diet. Saturated and monounsaturated fatty acids were the main components of white adipose tissues in rats fed on a low-fat diet. The fatty acid compositions in white adipose tissue of rats fed on diets containing $20 \%$ fats rich in $n-6$ or $n-3$ PUFA generally reflected those in dietary fat sources (data not shown).

\section{Discussion}

The present study confirmed that mRNA levels of several adipocyte proteins involved in the regulation of lipid and glucose metabolism and energy expenditure were profoundly modified by dietary fat content. Moreover, we have demonstrated that dietary fats rich in $n-3$ PUFA relative to safflower oil rich in $n-6$ PUFA affect gene expression of white and brown adipose tissues in different ways. There were some differences in the energy intake among groups in the present study. It was significantly higher in rats fed on a high-safflower-oil diet than in those fed low-fat and highfish-oil diets. Therefore, there is a concern that observed changes in gene expression are due to the differences in the energy intake rather than the modification of nutrient composition of the diet. However, it is apparent that there is no clear-cut relationship between levels of mRNA for 


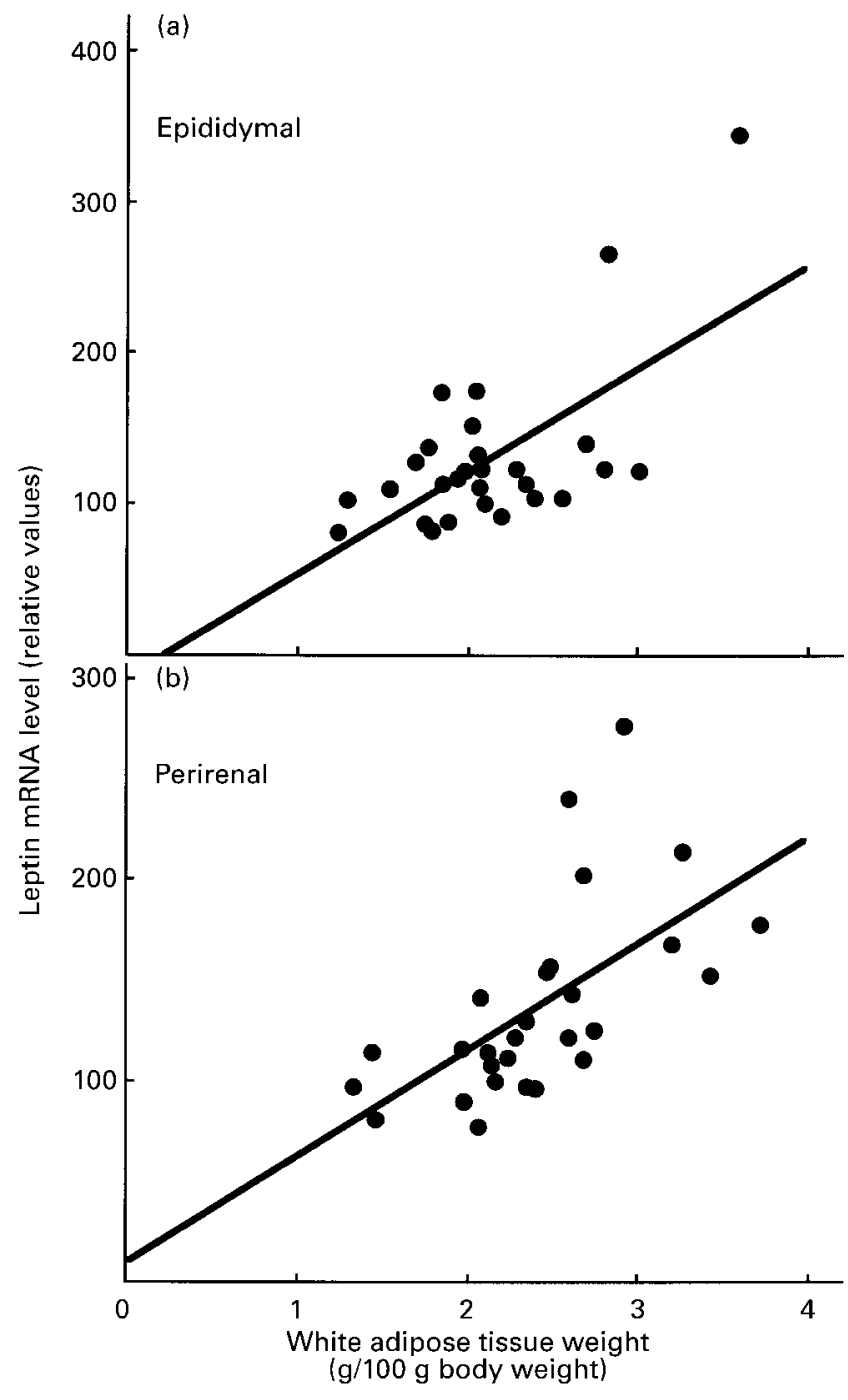

Fig. 3. Correlation between white adipose tissue weight and leptin mRNA level. (a) The correlation between epididymal adipose tissue weight and leptin mRNA level in this tissue. (b) The correlation between perirenal adipose tissue weight and leptin mRNA level in this tissue.

various proteins and energy intake among the groups. The increase in the energy intake appears to be one factor in enhancing UCP 1 mRNA level (Falcou et al. 1985). In spite of the fact that energy intake was the same among rats fed on a low-fat diet and those fed on high-fat diets containing perilla and fish oils, UCP1 mRNA level was significantly lower in a low-fat group than in high-perilla and -fish-oil diet groups. Moreover, UCP1 mRNA level in the high-safflower-oil group, which showed the highest energy intake, was the lowest among the high-fat groups. mRNA level of leptin was higher and that of Glut 4 was lower in rats fed on a high-safflower-oil diet than in those fed on a high-perilla-oil diet irrespective of the fact that the energy intake was the same between the two groups. All these observations indicate that observed changes in gene expression are principally due to the differences in diet composition rather than to those in energy intake.
Recent studies indicated that, compared to saturated fats and fats rich in $n$-6 PUFA (linoleic acid), fish oil rich in very-long-chain $n$-3 PUFA (eicosapentaenoic and docosahexaenoic acids) (Belzung et al. 1993; Oudart et al. 1997; Raclot et al. 1997; Kawada et al. 1998) and perilla oil rich in $\alpha$-linolenic acid (Okuno et al. 1997) reduced white fat pad mass. We also confirmed in the present study that both highperilla and -fish-oil diets reduced white fat pad mass compared to low-fat and high-safflower-oil diets.

It has been demonstrated that high-fat diets cause increased brown adipose tissue thermogenesis as assessed by mitochondrial guanosine $5^{\prime}$-diphosphate binding (Mercer \& Trayhurn, 1987; Oudart et al. 1997). Also, Giraudo et al. (1994) showed that a high-fat diet increased the brown adipose tissue UCP 1 mRNA level. These results agree with the present finding that high-fat diets greatly increased UCP 1 mRNA levels. In addition, in the present study, we demonstrated that both fish and perilla oils rich in $n$-3 PUFA increased brown fat UCP 1 mRNA level more than safflower oil rich in $n-6$ PUFA. It is plausible therefore that dietary $n$-3 PUFA increase non-shivering thermogenesis in brown adipose tissue through the enhancement of UCP 1 gene expression and hence reduce body fat content. A lack of a significant correlation between brown fat UCP 1 mRNA level and white adipose tissue mass, in the present study, may not be consistent with this assumption. In this context, there is the possibility that dietary fat content and types may also affect expressions of UCP 2 and 3, which are expressed in tissues other than brown adipose tissue and may play a crucial role in regulating energy expenditure (Fleury et al. 1997; Gong et al. 1997; Matsuda et al. 1997).

An increase of brown adipose tissue UCP 1 mRNA level by dietary $n$-3 PUFA is expected to accompany the increased amount of the translational product and hence enhance thermogenesis in this tissue. Kawada et al. (1998) compared the effects of lard, fish, linseed, and perilla oils added to a commercial diet at the level of $100 \mathrm{~g} / \mathrm{kg}$ on brown adipose tissue UCP 1 content. After feeding these experimental diets for 9 weeks, brown adipose tissue UCP 1 content measured by Western blotting was significantly higher in rats fed on a fish-oil diet than in those fed on a lard diet. Although the differences were not significant, the variable tended to be higher in rats fed on linseed- and perilla-oil diets than in those fed on a lard diet. In another study, Oudart et al. (1997) showed that brown fat mitochondrial guanosine $5^{\prime}$-diphosphate binding is higher in rats fed on high-fat diets $(200 \mathrm{~g} / \mathrm{kg}$ diet) rich in $n-3$ PUFA either as ethylesters of eicosapentaenoic or docosahexaenoic acid than in those fed on a high-fat diet or a low-fat diet devoid of $n$-3 PUFA after 4 weeks of the experimental period. They could not, however, demonstrate any difference in brown adipose tissue UCP 1 content among the groups. Therefore, the authors suggested that dietary $n-3$ PUFA do not increase UCP 1 mass but cause unmasking of guanosine $5^{\prime}$-diphosphate binding site of the protein. The reason for such discrepancy between these studies is not clear at present. Since there is the possibility that increased mRNA level does not necessarily accompany the corresponding increase in the translational product, further studies to clarify the effect of $n$-3 PUFA on brown adipose tissue UCP 1 mass are still required. 
Raclot et al. (1997) showed that reduction of retroperitoneal white fat cell weight by fish oil or ethylesters of eicosapentaenoic and docosahexaenoic acids accompanied the decreases in mRNA levels of several proteins expressed in this tissue. Okuno et al. (1997) indicated that perilla oil causes prevention of the adipose tissue growth suppressing the expression of the genes responsible for the late phase of adipocyte differentiation. However, their results did not provide the answer to the question on how extra energy is consumed to attenuate body fat accumulation in rats fed on $n$-3 PUFA.

Amount and type of dietary fat affect lipogenic activity not only in the liver but also in white adipose tissue (Nelson et al. 1987; Benhizia et al. 1994). A low-fat diet stimulates activity and mRNA level of fatty acid synthase in white adipose tissue, and they are down-regulated by increasing fat content in diet. Fish oil, compared to lard and corn oil, is more effective in decreasing these variables (Benhizia et al. 1994). Therefore, alteration in lipogenic activity in white adipose tissue together with up-regulation of brown adipose tissue UCP 1 gene expression can be regarded as one factor accounting for the physiological activity of $n-3$ PUFA in reducing white pad mass.

Leptin, the $o b$ gene product, is highly expressed in adipocytes and acts on the hypothalamus to regulate satiety and energy balance. Leptin infusion has clearly been demonstrated to reduce food intake and body weight in rodents (Zhang et al. 1994; Campfield et al. 1996). It has been demonstrated that high-fat diets increase gene expression of leptin in white adipose tissue obtained from various fats pads in rats (Masuzaki et al. 1995; Collins \& Surwit, 1996; Rousseau et al. 1997). It is reasonable to consider that this may represent a compensatory mechanism of the animals to control energy intake by reducing food intake in response to increased energy density of the diet. However, little attention has been paid to dietary fat types in evaluating leptin gene expression in these studies. In the present study, a high-safflower-oil diet doubled the leptin mRNA level in white adipose tissue, however, significant increases were not detected with high-fat diets rich in n-3 PUFA. Therefore, in the light of the present observations, a consensus that high-fat diets increase gene expression of leptin in white adipose tissue requires re-evaluation. Raclot et al. (1997) showed that $200 \mathrm{~g}$ fat $/ \mathrm{kg}$ diets containing fish oil or ethylesters of eicosapentaenoic and docosahexaenoic acids relative to a control diet containing $200 \mathrm{~g}$ fat mixture $/ \mathrm{kg}$ (mainly composed of oleic, palmitic and stearic acids) reduced leptin mRNA level in retroperitoneal white pad. Their study also supports the consideration that not only the fat content but also fat types in diet affect white adipose tissue leptin mRNA level. No correlation was observed between the leptin mRNA level and amounts of diet consumed or the energy intake in the present study. It has been demonstrated in studies with human subjects that a positive correlation exists between body fat mass and serum leptin concentration (Campfield et al. 1996; Takahashi et al. 1996; Qureshi \& Kopelman, 1997). These results indicated that most human obesity is not due to a deficiency of leptin. The result of the present study in rats demonstrated a significant positive correlation between leptin mRNA level and white pad mass. It is therefore suggested that alterations in leptin
mRNA level in the present study merely reflect those of fat pad mass but do not represent the specific effect of dietary fat types.

It has been demonstrated that high-fat feeding reduces the protein content and mRNA level of Glut 4 in white adipose tissue and muscle (Pedersen et al. 1991; Kahn, 1994; Sevilla et al. 1997). Down-regulation of Glut 4 gene expression may account for the reduction in the insulin-dependent glucose uptake in these tissues of rats fed on a high-fat diet. In these studies, however, little attention has been paid to whether dietary fat types affect Glut 4 gene expression. The present study confirmed that, compared to a low-fat diet, a highsafflower-oil diet profoundly reduced Glut 4 mRNA levels in epididymal and perirenal white adipose tissues. The reductions were, however, attenuated with high-fat diets rich in $n-3$ PUFA. It is apparent therefore that dietary fat types affect the gene expression of this protein. There is evidence indicating that dietary fish oil reduces the blood glucose level (Huang et al. 1997), improves glucose tolerance (Miura et al. 1997), and stimulates insulin-dependent glucose transport and metabolism in isolated adipocytes (Ezaki et al. 1996; Luo et al. 1996; Huang et al. 1997). We observed in the present study that a high-safflower-oil diet increased serum glucose concentration relative to a low-fat diet, but was not increased by high-fat diets rich in $n-3$ PUFA. Alterations in white adipose tissue Glut 4 gene expression observed in the present study may therefore account for the physiological activity of $n-3$ PUFA in regulating glucose metabolism.

In conclusion, we demonstrated that, compared to safflower oil rich in linoleic acid, dietary perilla and fish oils rich in $n$-3 PUFA affect the mRNA levels of proteins that regulate adipose tissue metabolism in a different manner. The results of the present study therefore suggested that not only the fat content but also the fat types are the critical determinant in regulating mRNA levels in adipose tissue. The observed changes may account for some of the physiological activities of $n-3$ PUFA in rats.

\section{References}

American Institute of Nutrition (1977) Report of the American Institute of Nutrition ad hoc Committee on Standards for Nutritional Studies. Journal of Nutrition 107, 1340-1348.

Belzung F, Raclot T \& Groscolas R (1993) Fish oil $n-3$ fatty acids selectively limit the hypertrophy of abdominal fat depots in growing rats fed high-fat diets. American Journal of Physiology 264, R1111-R1118.

Benhizia F, Hainault I, Serougne C, Lagrange D, Hajduch E, Guichard C, Malewiak MI, Quignard-Boulange A, Lavau M \& Griglio S (1994) Effects of a fish oil-lard diet on rat plasma lipoproteins, liver FAS, and lipolytic enzymes. American Journal of Physiology 267, E975-E982.

Bouillaud F, Ricquier D, Thibault J \& Weissenbach J (1985) Molecular approach to thermogenesis in brown adipose tissue: cDNA cloning of the mitochondrial uncoupling protein. Proceedings of the National Academy of Sciences of the USA 82, 445-448.

Bouillaud F, Weissenbach J \& Ricquier D (1986) Complete cDNA-derived amino acid sequence of rat brown fat uncoupling protein. Journal of Biological Chemistry 261, 1487-1490.

Brault D, Noe L, Etienne J, Hamelin J, Raisonnier A, Souli A, 
Chuat JC, Dugail I, Quignard-Boulange A, Lavau M \& Galibert F (1992) Sequence of rat lipoprotein lipase-encoding cDNA. Gene 121, 237-246.

Campfield LA, Smith FJ \& Burn P (1996) The OB protein (leptin) pathway - a link between adipose mass and central neural networks. Hormone and Metabolic Research 28, 619-632.

Chomczynski P \& Sacchi N (1987) Single-step method of RNA isolation by acid guanidinium thiocyanate-phenol-chloroform extraction. Analytical Biochemistry 162, 156-159.

Collins S \& Surwit RS (1996) Pharmacologic manipulation of $o b$ expression in a dietary model of obesity. Journal of Biological Chemistry 271, 9437-9440.

Ezaki O, Tsuji E, Momomura K, Kasuga M \& Itakura H (1992) Effect of fish and safflower oil feeding on subcellular glucose transporter distributions in rat adipocytes. American Journal of Physiology 263, E94-E101.

Falcou R, Bouillaud F, Mory G, Apfelbaum M \& Ricquier D (1985) Increase of uncoupling protein and its mRNA in brown adipose tissue of rats fed on 'cafeteria diet'. Biochemical Journal 231, 241-244.

Fleury C, Neverova M, Collins S, Raimbault S, Champigny O, Levi-Meyrueis C, Bouillaud F, Seldin MF, Surwit RS, Ricquier D \& Warden CH (1997) Uncoupling protein-2: a novel gene linked to obesity and hyperinsulinemia. Nature Genetics $\mathbf{1 5}$, 269-272.

Folch J, Lees M \& Sloane-Stanley GH (1957) A simple method for the isolation and purification of total lipids from animal tissues. Journal of Biological Chemistry 226, 497-509.

Giraudo SQ, Kotz CM, Grace MK, Levine AS \& Billington CJ (1994) Rat hypothalamic NPY mRNA and brown fat uncoupling protein mRNA after high-carbohydrate or high-fat diets. American Journal of Physiology 266, R1578-R1583.

Gong DW, He Y, Karas M \& Reitman M (1997) Uncoupling protein-3 is a mediator of thermogenesis regulated by thyroid hormone, $\beta 3$-adrenergic agonists, and leptin. Journal of Biological Chemistry 272, 24129-24132.

Himms-Hagen J (1990) Brown adipose tissue thermogenesis: interdisciplinary studies. FASEB Journal 4, 2890-2898.

Huang YJ, Fang VS, Juan CC, Chou YC, Kwok CF \& Ho LT (1997) Amelioration of insulin resistance and hypertension in a fructose-fed rat model with fish oil supplementation. Metabolism 46, $1252-1258$

Hwang CS, Loftus TM, Mandrup S \& Lane MD (1997) Adipocyte differentiation and leptin expression. Annual Review of Cell and Developmental Biology 13, 231-259.

Ide T, Kano S, Murata M, Yanagita T \& Sugano M (1994) Dietary modifications of the biliary bile acid glycine:taurine ratio and activity of hepatic bile acid-CoA : amino acid $\mathrm{N}$-acyltransferase (EC 2.3.1) in the rat. British Journal of Nutrition 72, 93 100.

Ide T, Okamatsu H \& Sugano M (1978) Regulation by dietary fats of 3-hydroxy-3-methylglutaryl-coenzyme A reductase in rat liver. Journal of Nutrition 108, 601-612.

Jacobsson A, Stadler U, Glotzer MA \& Kozak LP (1985) Mitochondrial uncoupling protein from mouse brown fat. Molecular cloning, genetic mapping, and mRNA expression. Journal of Biological Chemistry 260, 16250-16254.

James DE, Strube M \& Mueckler M (1989) Molecular cloning and characterization of an insulin-regulatable glucose transporter. Nature 338, 83-87.

Kahn BB (1994) Dietary regulation of glucose transporter gene expression: tissue specific effects in adipose cells and muscle. Journal of Nutrition 124, 1289S-1295S.

Kawada T, Kayahashi S, Hida Y, Koga K, Nadachi Y \& Fushiki T (1998) Fish (Bonito) oil supplementation enhances the expression of uncoupling protein in brown adipose tissue of rat. Journal of Agricultural and Food Chemistry 46, 1225-1227.
Kirchgessner TG, Svenson KL, Lusis AJ \& Schotz MC (1987) The sequence of cDNA encoding lipoprotein lipase. A member of a lipase gene family. Journal of Biological Chemistry 262, 84638466.

Luo J, Rizkalla SW, Boillot J, Alamowitch C, Chaib H, Bruzzo F, Desplanque N, Dalix AM, Durand G \& Slama G (1996) Dietary $(n-3)$ polyunsaturated fatty acids improve adipocyte insulin action and glucose metabolism in insulin-resistant rats: relation to membrane fatty acids. Journal of Nutrition 126, 19511958.

Martin I, Giralt M, Viñas O, Iglesias R, Mampel T \& Villarroya F (1995) Co-ordinate decrease in the expression of the mitochondrial genome and nuclear genes for mitochondrial proteins in the lactation-induced mitochondrial hypotrophy of rat brown fat. Biochemical Journal 308, 749-752.

Matsuda J, Hosoda K, Itoh H, Son C, Doi K, Tanaka T, Fukunaga Y, Inoue G, Nishimura H, Yoshimasa Y, Yamori Y \& Nakao K (1997) Cloning of rat uncoupling protein-3 and uncoupling protein-2 cDNAs: their gene expression in rats fed high-fat diet. FEBS Letters 418, 200-204.

Masuzaki H, Ogawa Y, Hosoda K, Kawada T, Fushiki T \& Nakao K (1995) Augmented expression of the obese gene in the adipose tissue from rats fed high-fat diet. Biochemical and Biophysical Research Communications 216, 355-358.

Mercer SW \& Trayhurn P (1987) Effect of high fat diets on energy balance and thermogenesis in brown adipose tissue of lean and genetically obese ob/ob mice. Journal of Nutrition 117, 21472153.

Miura T, Ohnishi Y, Takagi S, Sawamura M, Yasuda N, Ishida H, Tanigawa K, Yamori Y \& Seino Y (1997) A comparative study of high-fat diet containing fish oil or lard on blood glucose in genetically diabetic $(\mathrm{db} / \mathrm{db})$ mice. Journal of Nutritional Science and Vitaminology 43, 225-231.

Nelson GJ, Kelly DS, Schmidt PC \& Serrato CM (1987) The influence of dietary fat on the lipogenic activity and fatty acid composition of rat white adipose tissue. Lipids 22, 338344.

Nicholls DG \& Locke RM (1984) Thermogenic mechanisms in brown fat. Physiological Reviews 64, 1-64.

Ogawa Y, Masuzaki H, Isse N, Okazaki T, Mori K, Shigemoto M, Satoh N, Tamura N, Hosoda K, Yoshimasa Y, Jingami H, Kawada T \& Nakao K (1995) Molecular cloning of rat obese cDNA and augmented gene expression in genetically obese Zucker fatty $(f a / f a)$ rats. Journal of Clinical Investigation 96, 1647-1652.

Okuno M, Kajiwara K, Imai S, Kobayashi T, Honma N, Maki T, Suruga K, Goda T, Takase S, Muto Y \& Moriwaki H (1997) Perilla oil prevents the excessive growth of visceral adipose tissue in rats by down-regulating adipocyte differentiation. Journal of Nutrition 127, 1752-1757.

Oudart H, Groscolas R, Calgari C, Nibbelink M, Leray C, Maho YL \& Malan A (1997) Brown fat thermogenesis in rats fed high-fat diets enriched with $n-3$ polyunsaturated fatty acids. International Journal of Obesity 21, 955-962.

Pedersen O, Kahn CR, Flier JS \& Kahn BB (1991) High fat feeding causes insulin resistance and a marked decrease in the expression of glucose transporters (Glut 4) in fat cells of rats. Endocrinology 129, 771-777.

Qureshi A \& Kopelman PG (1997) Leptin - fat messenger or fat controller? Clinical Endocrinology 47, 169-171.

Raclot T, Groscolas R, Langin D \& Ferré P (1997) Site-specific regulation of gene expression by $n-3$ polyunsaturated fatty acids in rat white adipose tissues. Journal of Lipid Research 38, $1963-$ 1972.

Ramsay TG (1996) Fat cells. Endocrinology and Metabolism Clinics of North America 25, 847-870.

Ricquier D, Bouillaud F, Toumelin P, Mory G, Bazin R, Arch J \& 
Pénicaud L (1986) Expression of uncoupling protein mRNA in thermogenic or weakly thermogenic brown adipose tissue. Evidence for a rapid $\beta$-adrenoreceptor mediated and transcriptionally regulated step during activation of thermogenesis. Journal of Biological Chemistry 261, 13905-13910.

Ricquier D, Mory G, Bouillaud F, Thibault J \& Weissenbach J (1984) Rapid increase of mitochondrial uncoupling protein and its mRNA in stimulated brown adipose tissue. FEBS Letters $\mathbf{1 7 8}$, 240-244.

Rousseau V, Becker DJ, Ongemba LN, Rahier J, Henquin JC \& Brichard SM (1997) Developmental and nutritional changes of $o b$ and PPAR gamma 2 gene expression in rat white adipose tissue. Biochemical Journal 321, 451-456.

Semenkovich CF, Chen SH, Wims M, Luo CC, Li WH \& Chan L (1989) Lipoprotein lipase and hepatic lipase mRNA tissue specific expression, developmental regulation, and evolution. Journal of Lipid Research 30, 423-431.

Sevilla L, Gumà A, Enrique-Tarancòn G, Mora S, Muñz P, Palacín M, Testar X \& Zorzano A (1997) Chronic high-fat feeding and middle-aging reduce in an additive fashion Glut4 expression in skeletal muscle and adipose tissue. Biochemical and Biophysical Research Communications 235, 89-93.

Snedecor GW \& Cochran WG (1989) Statistical Methods, 8th ed. Ames, IA: Iowa State University Press.

Takahashi M, Funahashi T, Shimomura I, Miyazaki K \& Matsuzawa Y (1996) Plasma leptin levels and body fat distribution. Hormone and Metabolic Research 28, 751-762.

Zhang Y, Proenca R, Maffei M, Barone M, Leopold L \& Friedman JM (1994) Positional cloning of the mouse obese gene and its human homologue. Nature 372, 425-432. 